OBITUARY.

\author{
Dr. Edward Daniel O'Neill.
}

By the death on January 12th of Dr. Edward Daniel O' Neill the Asylum Service of Ireland has lost one of its most capable administrators. His symptoms did not appear to be of serious import until a comparatively short time before his demise. His health, however, had been a good deal impaired for some time past, and he suffered more or less from chronic insomnia and gouty attacks. He was sixty-three years of age, and had been for twenty-six years in charge of the Limerick District Asylum, in which capacity he had won the confidence and esteem of his Committee of Management, of the Inspectors, and of the public generally. His medical education he obtained in the Carmichael School of Medicine in Dublin, where he took the diplomas of L.R.C.S. (1872), L.R.C.P. (1878), and M.R.C.P.I. (1884). He was for five years (1881-1886) Assistant Medical Officer at the Richmond Asylum, Dublin, and from there was promoted to be Medical Superintendent of Castlebar Asylum, where he remained for four years, and in 1890 he succeeded in obtaining the similar but more important post in Limerick Asylum. Dr. O'Neill took a warm interest in the welfare of his patients, whom he treated with invariable kindness and consideration. His courtesy towards all with whom he had to do will be a grateful reminiscence in the minds of many. He was a representative member of the Council of the Association, and attended the Quarterly Meeting in London in November last. His too early removal has occasioned the deepest regret to his colleagues in Ireland, and indeed to everyone who had the pleasure of knowing and appreciating his genial personality.

\title{
Lieutenant Edgar Faulks, R.A.M.C.
}

The speciality has sustained a loss by the death of Lieutenant Edgar Faulks, R.A.M.C., late Senior Assistant Medical Officer of the London County Asylum, Bexley, which took place on September 26 th last whilst he was dressing a wounded man in the fighting line near Loos in France.

Dr. Faulks, who was the son of Mr. and Mrs. Arthur Faulks, of Loughborough, Leicestershire, was 38 years of age, and received his medical education at Guy's Hospital, where he held a number of resident appointments, and during which time he was President of the Residents' Club. He was appointed Junior Assistant Medical Officer at Bexley, and during eleven years' service there he steadily rose, and was for the latter five years Senior Assistant Medical Officer. He was a very keen student, and took a deep interest in all new developments in the treatment, care, and housing of the insane. He was a very able clinician, and his opinion, owing to his well-balanced judgment, was always much sought by his colleagues. He had a very delightful personality, and entered very fully into the life of the Institution.

A special Memorial Service was held in the Asylum Church on the Sunday following the news of his death. Beloved alike by his colleagues and by the patients and staff, the death of Dr. Edward Faulks has left to all who knew him a deep sense of personal bereavement.

\section{CORRESPONDENCE.}

To the President and the Members of the "Medico-Psychological Association."

Gentremen, - I take the liberty of soliciting your kind support in the interests of juvenile defectives in Belgium, and more especially in the Province of Brabant. This question was in a fair way of being solved at the time of the outbreak of the war, and the provincial authorities of Brabant had decided to erect an institution for the "feeble-minded" at Waterloo. The construction of this establishment had begun when the war broke out, and all the operations were stopped.

It is to be feared, and news from Belgium confirm this apprehension, that the heavy expenses that our country will ultimately have to meet will be a pretext for 